\title{
Consistency of Quality Management in Slovenian Organizations
}

\author{
Vinko Bogataj \\ Independent researcher, Slovenia \\ Gordana Žurga \\ Faculty of Organisation Studies in Novo mesto, Slovenia
}

\section{Abstract}

Background: Having efficient quality management system (QMS) is vital for improving organization's business. In that context, good knowledge of QMS characteristics and their interrelations with organizational business results is very important. Objectives: Purpose of the study is to explore characteristics of elements of QMS consistency in Slovene organizations that have implemented and maintained QMS, and how the QMS characteristics influence business results. Methods/Approach: Data was collected through web survey of quality managers in organizations that have certified QMS according to ISO 9001:2008. For respondent organizations, data on their business results was retrieved from official sources. Special programme for comparisons and results presentation based on contingency analysis was developed, and correlation between QMS consistency elements and financial results of organizations were statistically processed. Results: The results show that for Slovenian organizations with certified QMS, correlations between QMS consistency elements and organizational business results are confirmed. For the majority of consistency elements correlations are significant, and the elements where correlations are insignificant are also exposed. Conclusions: As quality management will gradually become integral part of holistic organizational management, QMS will influence not only organizational management system and processes' management but also directly on business results.

Keywords: quality management system, QMS, consistency, business results, Slovenia. JEL classification: D20, L15, L25, M21

Paper type: Research article

Received: Nov 27, 2017

Accepted: Jan 27, 2018

Citation: Bogataj, V., Žurga, G. (2018), "Consistency of Quality Management in Slovenian Organizations", Business Systems Research, Vol.9, No.1, pp. 78-92.

DOI: 10.2478/bsrj-2018-0007

\section{Introduction}

Quality management system (QMS) is indispensable part of management system of an organization. For organization, it is important to develop and constantly improve its operations and achieve competitive advantage. Having efficient QMS is one of approaches for improving organization's business. In last decades, several authors researched how QMSs contribute to organizational performance and business results (Kaynak, 2003; Prajogo et al., 2003; Yeung et al., 2006; Saizarbitoria, 2006; Alič, 2014). 
Different aspects of QMSs were explored to understand causalities in this respect, e. g. regarding implementation of QMSs (Bell et al., 2011; Brown, 2013), integration of different management systems (Asif et al., 2010; Karapetrović et al., 2009), role of leadership and ways of decision-making (Akdere, 2011; Doeleman et al., 2012; Elg et al., 2011; Larson et al., 2010), role of employees and their competencies (Werner et al., 2012; Zelnik et al., 2012), or innovation aspects of QMSs (Dong-Yung et al., 2012).

These studies report that different characteristics of organizations and their environment (business, societal, technological, legal, natural, etc.) have important impact on contribution of organizational QMS to the results achieved. QMS that organizations have must be adequate for their own organizational characteristics and products they produce or to the demands of internal and external environment of organizations. Some studies, i.e. Prajogo et al. (2003) show strong positive impact of QMS on organizational results while others, i.e. Yeung et al. (2006) report of substantially less favourable impact.

Purpose of this paper is to explore characteristics of elements of QMS consistency in Slovene organizations that have implemented and maintained QMS according to the ISO 9000 quality standards, and how these QMS characteristics influence business results. The methodology applied is a combination of a survey of quality managers, analysis of financial data and statistical methods.

The study presented in the paper contributes to understanding interrelations between characteristics of quality management systems and organizational business results. In comparison to previous researches, added value of this research is not only in the set of relations between elements of consistency and other characteristics of QMS but also in addressing the gap between actual and needed organizational characteristics of QMS and to its influence on business effectiveness.

In the paper, we first present review of literature and relevant researches, and set the hypothesis. In continuation the methodology is described, followed by presentation and analysis of the results. Within the discussion, first the summary of the research and the conclusions are given, limitations of the research and practical implications are presented, and areas for further research and investigation are indicated.

\section{Literature Review}

In continuation, we present overview of some important findings of researchers that explored area of QMS characteristics and their influence on business characteristics of observed organizations.

Zhang et al. (2012) explored relationship between QMS practice and business characteristics of organizations. The research was conducted in 238 manufacturing organizations in eight states: Austria, Finland, Germany, Italy, Japan, South Korea, Sweden and USA. The authors divided characteristics of QMS into "Quality Exploitation« and »Quality Exploration«. The first term denotes elements of QMS usage while the latter addresses elements of capabilities to improve QMS. The results show that both, internal adjustment of QMS to organizational structure as well QMS's adjustment to uncertainties in the environment, reflect on organization's business characteristics.

On the bases of Resource Dependence Theory (RDT), Singh et al. (2011) analysed correlations between individual elements of QMS. The analysis was conducted in 416 Australian manufacturing organizations with QMS certified according to ISO 9001 quality standards. They divided characteristics of QMS practice into internal processes (nine elements), relations with customers (six elements), relations with suppliers (5 elements), and functional characteristics (seven elements). Authors 
found out that in observed organizations ISO 9000 principles detectable but not strongly influence business characteristics of internal processes.

Nair (2006) preformed comparative analysis of researches conducted by key authors between 1995 and 2004 on correlation between QMS practice and business characteristics of organizations. Author's finding was that studies performed proved direct connection between QMS practice and results. Exploration of relations between QMS practice and organizational results may serve also as bases improving theoretical approach to QMS. Nair exposes that in future explorations, attention should be given to the role of ımoderation factors" when testing influence of QMS on organizational results measuring. By the term »moderation factors author denotes factors that influence in such a way that similar situations in the QMS area in similar organizations lead to completely different results.

Martinez-Costa et al. (2009) explored difference between QMS according to standards ISO 9000:1994 and ISO 9000:2000. Research was conducted in 713 Spanish industrial companies. By multivariable analysis of variance (MANOVA) and variance analysis (ANOVA) authors did not manage to prove better results for organizations with QMS according to ISO $9000: 2000$ as for those organizations with QMS according to ISO 9000:1994. However, they proved that in the first ones total quality management elements were presented more strongly.

Conti (2010) deals with different and sometime even illogical phenomena in quality management theory development. He summarises results of experiments on orientation of quality and system(ic) thinking in processes that create value. On the first place, author puts need for inclusion of modern system insight into quality management. On the second place is the key role of group system thinking in creating value. Techniques and technologies are of course important however, they do not do the changes needed and are also not at most essential for competitiveness. Fragmented view on management is not only problem of quality management but of management in general. Source of the problem is in strategic fragmentation, lack of system perspective, silos organization and excessive specialisation.

Liebesman (2008) states that organizations today have several management systems such as financial management, quality management, environment management etc. that very often do not communicate. They behave as independent organization subsystems (silos) that do not achieve optimal results. Unsatisfied customers as well owners are their logical consequence. Quality system managers (QSM) have to understand language of finance, and financial managers have to understand how QMS can improve financial results. Long-term advantages of organizations are in efficient continuous improvements of processes and products, and in greater understanding of work and responsibilities of co-workers in other processes.

Singh et al. (2011) in their QMS practice model in observed organizations divide characteristics of QMS practice into: elements of relations with customers, elements of relations to suppliers, elements of internal processes, and elements of functional characteristics of QMS practice. However, they do not consider (explore) organizational and functional characteristics of QMS. Sommerhoff $(2012,2013)$ in his work considers also different factors that have influence on characteristics of quality managers' functions.

Several authors such as Yeung et al. (2006), Nair (2006), Conti (2010) and Liebesman (2008) argue that practically the same QMSs in similar organizations provide different results. Reason for this could be searched for in different manners how the management operates, in different relations between top and middle 
management, in different organizational culture and in other differences in organizations that have influence on characteristics of QMS and therefore on its functioning.

\section{Methodology}

Research instrument

The main research question and our aim is to explore characteristics of elements of QMS consistency in Slovene organizations that have implemented and maintained QMS, and how the QMS characteristics influence business results of organizations. Relations between elements of QMS consistency and other QMS characteristics are illustrated in Figure 1.

Figure 1

Relations between elements of consistency and other characteristics of QMS

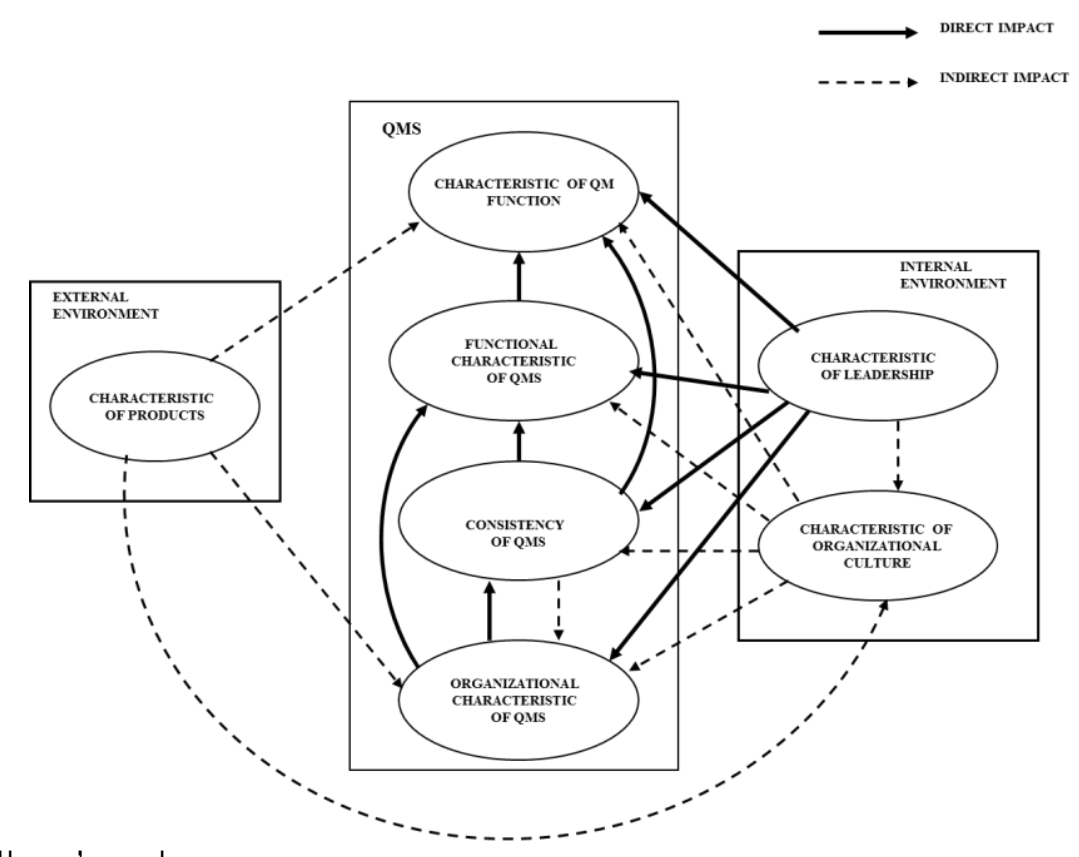

Source: Authors' work

As elements of QMS consistency in this research, we defined characteristics of QMS as presented in Table 1.

For the research, following hypothesis was set:

H1: In organizations in the Republic of Slovenia that have implemented and maintained QMS, it is possible to confirm relations between elements of the QMS consistency and business results of organizations.

\section{Data}

The research question considered in this article is part of a broader research conducted in the period 2014 - 2016. The main part of empirical research was performed via web survey of quality managers in organizations in the Republic of Slovenia that have certified QMS according to ISO 9001:2008. According to the data of certification organs, in January 2013 there were 1878 such organizations in Slovenia. The web survey among quality mangers was performed between June 2014 and April 2015. Web survey was supported by web tool 'Kwiksurveys'. 
Quality managers were invited as appropriate respondents as they at most know QMS in their organizations. The questionnaire for quality managers was composed of 76 questions, and five-level Likert scale was used for providing the data from respondents.

After closing the survey, for organizations that co-operated in the research we then retrieved their business results from the Agency of Republic of Slovenia for public legal records and related services (AJPES, 2015). Their financial data were then categorised according to Likert scale from one to five. Following financial data were analysed: income growth level 201 1-2014; added value growth level 2011-2014; income growth level 2013-2014; added value growth level 2013-2014; added value level 2014.

142 filled-in questionnaires were received by quality managers however, only 132 of them were fully completed. Financial data on business operation were available for 126 (out of 132) organizations.

\section{Table 1}

Consistency elements included in the research

\begin{tabular}{|c|c|c|}
\hline No. & Consistency element & Description \\
\hline 1 & $\begin{array}{l}\text { Role of processes' owners in control of } \\
\text { goals' achievement and processes' } \\
\text { improvement }\end{array}$ & $\begin{array}{l}\text { Careful control and constant care of processes' owners } \\
\text { for improvement of their respective processes is of a } \\
\text { key importance for successful organizational business. }\end{array}$ \\
\hline 2 & $\begin{array}{l}\text { Level of quality management principles } \\
\text { establishment, according to ISO 9004:2009 }\end{array}$ & $\begin{array}{l}\text { Customer focus (2a); Leadership (2b); Involvement of } \\
\text { people (2c); Process approach (2d); System approach } \\
\text { to management (2e); Continual improvement ( } 2 \mathrm{f}) \text {; } \\
\text { Factual approach to decision making (2g); Mutually } \\
\text { beneficial supplier relationships (2h). }\end{array}$ \\
\hline 3 & $\begin{array}{l}\text { Level of responsibility of the sales } \\
\text { department for resolving customers' } \\
\text { complaints }\end{array}$ & $\begin{array}{l}\text { Responsibility of the sales department for resolving } \\
\text { customers' complaints is of great importance due to } \\
\text { correct relationship to customers. With high level of this } \\
\text { responsibility, we prevent deception of customers. }\end{array}$ \\
\hline 4 & $\begin{array}{l}\text { Level of usage of QMS as a system for } \\
\text { managing organization }\end{array}$ & $\begin{array}{l}\text { QMS has to be a system for managing organization. } \\
\text { Any other approach means that QMS is there for itself. }\end{array}$ \\
\hline 5 & $\begin{array}{l}\text { Considering actions and recommendations } \\
\text { from internal and external audits in } \\
\text { implementing organizational changes by } \\
\text { the management }\end{array}$ & $\begin{array}{l}\text { High level of consideration of recommendations from } \\
\text { internal and external audits gives the QMS important } \\
\text { component for usage of the QMS as a system for } \\
\text { managing organization. }\end{array}$ \\
\hline 6 & $\begin{array}{l}\text { Considering actions and recommendations } \\
\text { from management review in implementing } \\
\text { organizational changes by the } \\
\text { management }\end{array}$ & $\begin{array}{l}\text { High level of consideration of recommendations from } \\
\text { management review is key element for usage of the } \\
\text { QMS as a system for managing organization. }\end{array}$ \\
\hline 7 & $\begin{array}{l}\text { Level of responsibility of processes' owners } \\
\text { for reporting to the management }\end{array}$ & $\begin{array}{l}\text { High level of responsibility of processes' owners for } \\
\text { reporting to the management is key element of settled } \\
\text { internal relationships in organization. }\end{array}$ \\
\hline
\end{tabular}

Source: Authors' work

\section{Statistical methods}

After closing the survey, the data was processed statistically in 'Excel'. Comparative questions from the questionnaire that relate to actual and needed characteristics of QMS consistency were processed with program package 'Mathematica'. We developed a special programme for comparisons and results presentation based on contingency analysis.

Shares of status change $\hat{p}$ are given by confidence interval $\mathrm{Cl}_{s}(1-\mathrm{a}=0.95 ; \mathrm{z}=1.96)$ that is calculated on the basis of Formula 1. 


$$
C I_{s}=\hat{p} \pm z \cdot \sqrt{\frac{\hat{p} \cdot(1-\hat{p})}{N}} \quad ; \quad N=126
$$

Questions that relate to correlation between QMS consistency elements and financial results of organizations were statistically processed with statistical programme 'Statistica'. Pearson's correlation coefficients $(r)$ were calculated upon Formula 2, for the confidence level $(1-a=0.95)$.

$$
\begin{gathered}
r=\frac{S x y}{\sqrt{S x x \cdot S y y}} ; \text { where } \\
\mathrm{Sxy}=\sum_{i=1}^{n}(x i-\bar{x}) \cdot(y i-\bar{y}) ; \mathrm{Sxx}=\sum_{i=1}^{n}(x i-\bar{x})^{2} ; \mathrm{Syy}=\sum_{i=1}^{n}(y i-\bar{y})^{2}
\end{gathered}
$$

The significance limit of Pearson's correlation coefficient (PCC) is for given number of organizations $(N=126)$ and confidence level $(1-a=0.95)$ at 0.17488 . In the article, all significant correlation coefficients are bolded and, within tables also additionally shaded. All other correlation coefficients are statistically insignificant.

\section{Results}

In Table 2 key shares and confidence intervals (confidence level $a=0.95$ ) for elements of QMS consistency are presented. Among basic quality management principles according to ISO 9004:2009 (customer focus, leadership, involvement of people, process approach, system approach to management, continual improvement, factual approach to decision making, and mutually beneficial supplier relationships) the most established principle is customer focus (Slovenski inštitut za standardizacijo, 2009). Population share of establishment level of a principle is within the interval $\{0.60 ; 0.76\}$.

The highest increase in level of a principle establishment that quality managers want is for involvement of people and continual improvement. It is interesting that quality managers in the majority of basic quality principles do not prefer very high level of principle establishment but only high level. The exception is at principle customer focus where it is evident that quality managers want very high level of its establishment.

In respect to other elements of QMS consistency, quality managers are the most satisfied with the following:

- the level of consideration of actions and recommendations from internal and external audits (population share of satisfied quality managers is within interval $\{0,51 ; 0,69\})$,

- the management review (population share of satisfied quality managers is within interval $\{0.51 ; 0.69\}$ ) when implementing organizational changes by the management.

Also with other consistency elements, it is evident that quality managers in most cases do not prefer very high level of establishment of consistency elements, but only high level. The highest level (in this) quality managers want within responsibility level of processes' owners for reporting to the management (population share of desired positive changes is within interval $\{0.43 ; 0.61\}$ ), and within using QMS as a 
system for managing the organization (population share of desired positive changes is within interval $\{0.39 ; 0.57\}$ ).

\section{Table 2}

Shares and confidence intervals for key elements of QMS consistency $(1-a=0.95)$

\begin{tabular}{|c|c|c|c|c|c|c|c|}
\hline \multirow[t]{2}{*}{ No } & \multirow[t]{2}{*}{$\begin{array}{l}\text { Organizational characteristics of } \\
\text { QMS }\end{array}$} & \multicolumn{2}{|c|}{ Appropriate } & \multicolumn{2}{|c|}{$\begin{array}{l}\text { Needs to be } \\
\text { increased }\end{array}$} & \multicolumn{2}{|c|}{$\begin{array}{l}\text { Needs to be } \\
\text { decreased }\end{array}$} \\
\hline & & Share & $\begin{array}{l}\text { Confidence } \\
\text { interval }\end{array}$ & Share & $\begin{array}{c}\text { Confidence } \\
\text { interval }\end{array}$ & Share & $\begin{array}{l}\text { Confidence } \\
\text { interval }\end{array}$ \\
\hline 1 & $\begin{array}{l}\text { Role of processes' owners in control } \\
\text { of goals' achievement and } \\
\text { processes' improvement }\end{array}$ & 0.48 & $\{0.39 ; 0.57\}$ & 0.48 & $\{0.39 ; 0.57\}$ & 0.04 & $\{0.01 ; 0.07\}$ \\
\hline $2 a$ & $\begin{array}{l}\text { Level of basic quality management } \\
\text { principle establishment - customer } \\
\text { focus }\end{array}$ & 0.68 & $\{0.60 ; 0.76\}$ & 0.30 & $\{0.22 ; 0.38\}$ & 0.02 & $\{0.00 ; 0.04\}$ \\
\hline $2 b$ & $\begin{array}{l}\text { Level of basic quality management } \\
\text { principle establishment - leadership }\end{array}$ & 0.60 & $\{0.51 ; 0.69\}$ & 0.38 & $\{0.30 ; 0.46\}$ & 0.02 & $\{0.00 ; 0.04\}$ \\
\hline $2 c$ & $\begin{array}{l}\text { Level of basic quality management } \\
\text { principle establishment - } \\
\text { involvement of people }\end{array}$ & 0.38 & $\{0.30 ; 0.46\}$ & 0.60 & $\{0.51 ; 0.69\}$ & 0.02 & $\{0.00 ; 0.04\}$ \\
\hline $2 d$ & $\begin{array}{l}\text { Level of basic quality management } \\
\text { principle establishment - process } \\
\text { approach }\end{array}$ & 0.52 & $\{0.44 ; 0.60\}$ & 0.45 & $\{0.36 ; 0.54\}$ & 0.02 & $\{0.00 ; 0.04\}$ \\
\hline $2 e$ & $\begin{array}{l}\text { Level of basic quality management } \\
\text { principle establishment - system } \\
\text { approach to management }\end{array}$ & 0.49 & $\{0.40 ; 0.58\}$ & 0.48 & $\{0.39 ; 0.57\}$ & 0.02 & $\{0.00 ; 0.04\}$ \\
\hline $2 f$ & $\begin{array}{l}\text { Level of basic quality management } \\
\text { principle establishment - continual } \\
\text { improvement }\end{array}$ & 0.42 & $\{0.33 ; 0.51\}$ & 0.56 & $\{0.47 ; 0.65\}$ & 0.02 & $\{0.00 ; 0.04\}$ \\
\hline $2 g$ & $\begin{array}{l}\text { Level of basic quality management } \\
\text { principle establishment - factual } \\
\text { approach to decision making }\end{array}$ & 0.56 & $\{0.47 ; 0.65\}$ & 0.40 & $\{0.31 ; 0.49\}$ & 0.04 & $\{0.01 ; 0.07\}$ \\
\hline $2 \mathrm{~h}$ & $\begin{array}{l}\text { Level of basic quality management } \\
\text { principle establishment - mutually } \\
\text { beneficial supplier relationships }\end{array}$ & 0.55 & $\{0.46 ; 0.64\}$ & 0.44 & $\{0.35 ; 0.53\}$ & 0.01 & $\{0.00 ; 0.03\}$ \\
\hline 3 & $\begin{array}{l}\text { Level of responsibility of the sales } \\
\text { department for resolving customers' } \\
\text { complaints }\end{array}$ & 0.52 & $\{0.43 ; 0.61\}$ & 0.45 & $\{0.36 ; 0.54\}$ & 0.02 & $\{0.00 ; 0.04\}$ \\
\hline 4 & $\begin{array}{l}\text { Level of usage of QMS as a system } \\
\text { for managing organization }\end{array}$ & 0.48 & $\{0.39 ; 0.57\}$ & 0.48 & $\{0.39 ; 0.57\}$ & 0.04 & $\{0.01 ; 0.07\}$ \\
\hline 5 & $\begin{array}{l}\text { Considering actions and } \\
\text { recommendations from internal and } \\
\text { external audits in implementing } \\
\text { organizational changes by the } \\
\text { management }\end{array}$ & 0.60 & $\{0.51 ; 0.69\}$ & 0.39 & $\{0.30 ; 0.48\}$ & 0.02 & $\{0.00 ; 0.04\}$ \\
\hline 6 & $\begin{array}{l}\text { Considering actions and } \\
\text { recommendations from } \\
\text { management review in } \\
\text { implementing organizational } \\
\text { changes by the management }\end{array}$ & 0.60 & $\{0.51 ; 0.69\}$ & 0.36 & $\{0.28 ; 0.44\}$ & 0.04 & $\{0.01 ; 0.07\}$ \\
\hline 7 & $\begin{array}{l}\text { Level of responsibility of processes' } \\
\text { owners for reporting to the } \\
\text { management }\end{array}$ & 0.48 & $\{0.39 ; 0.57\}$ & 0.52 & $\{0.43 ; 0.61\}$ & 0.01 & $\{0.00 ; 0.03\}$ \\
\hline
\end{tabular}

Source: Authors' work 
In the Table 3, correlations between individual elements of QMS consistency and financial results of organizations are given.

\section{Table 3}

Pearson correlation coefficients between elements of QMS consistency and financial results of organizations $(N=126 ; 1-a=0.95)$

\begin{tabular}{|c|c|c|c|c|c|c|c|c|}
\hline No. & $\begin{array}{l}\text { Elements of QMS } \\
\text { consistency }\end{array}$ & Avg. & $\begin{array}{l}\text { Standard } \\
\text { deviation }\end{array}$ & $\begin{array}{l}\text { Income } \\
\text { growth } \\
\text { level } \\
2013- \\
2014\end{array}$ & $\begin{array}{l}\text { Added } \\
\text { value } \\
\text { growth } \\
\text { level } \\
2013- \\
2014\end{array}$ & $\begin{array}{l}\text { Income } \\
\text { growth } \\
\text { level } \\
2011 \text { - } \\
2014\end{array}$ & $\begin{array}{l}\text { Added } \\
\text { value } \\
\text { growth } \\
\text { level } \\
2011- \\
2014\end{array}$ & $\begin{array}{l}\text { Added } \\
\text { value } \\
\text { level } \\
2014\end{array}$ \\
\hline 1 & $\begin{array}{l}\text { Role of processes' owners } \\
\text { in control of goals' } \\
\text { achievement and } \\
\text { processes' improvement }\end{array}$ & 3.7460 & 0.8479 & 0.1801 & 0.1134 & 0.1801 & 0.1268 & 0.2802 \\
\hline $2 a$ & Customer focus & 4.2857 & 0.7679 & 0.1989 & 0.1252 & 0.2799 & 0.0810 & 0.2726 \\
\hline $2 b$ & Leadership & 3.8730 & 0.8484 & 0.1800 & 0.0333 & 0.2734 & 0.0000 & 0.2000 \\
\hline $2 c$ & Involvement of people & 3.5317 & 0.8068 & 0.0982 & 0.0841 & 0.1753 & -0.0140 & 0.1262 \\
\hline $2 d$ & Process approach & 3.6429 & 0.7638 & 0.0148 & -0.0518 & 0.1185 & -0.0148 & 0.0963 \\
\hline $2 e$ & $\begin{array}{l}\text { System approach to } \\
\text { management }\end{array}$ & 3.5873 & 0.7618 & 0.1485 & 0.1114 & 0.1337 & 0.1337 & 0.2005 \\
\hline $2 f$ & Continual improvement & 3.6746 & 0.9106 & 0.1118 & 0.0559 & 0.1988 & 0.0248 & 0.2485 \\
\hline $2 g$ & $\begin{array}{l}\text { Factual approach to } \\
\text { decision making }\end{array}$ & 3.8889 & 0.7180 & 0.0867 & -0.0158 & 0.1418 & 0.0236 & 0.1418 \\
\hline $2 \mathrm{~h}$ & $\begin{array}{l}\text { Mutually beneficial } \\
\text { supplier relationships }\end{array}$ & 3.7778 & 0.7471 & 0.1817 & 0.1969 & 0.2801 & 0.2574 & 0.2877 \\
\hline 3 & $\begin{array}{l}\text { Level of responsibility of } \\
\text { the sales department for } \\
\text { resolving customers' } \\
\text { complaints }\end{array}$ & 3.7857 & 0.9261 & 0.1222 & 0.0672 & 0.0672 & -0.0244 & 0.1466 \\
\hline 4 & $\begin{array}{l}\text { Level of usage of QMS as } \\
\text { a system for managing } \\
\text { organization }\end{array}$ & 3.5079 & 0.9011 & 0.1444 & 0.0691 & 0.1381 & 0.0126 & 0.1444 \\
\hline 5 & $\begin{array}{l}\text { Considering actions and } \\
\text { recommendations from } \\
\text { internal and external } \\
\text { audits in implementing } \\
\text { organizational changes } \\
\text { by the management }\end{array}$ & 3.6825 & 0.9091 & 0.1991 & 0.0809 & 0.1929 & 0.0684 & 0.1618 \\
\hline 6 & $\begin{array}{l}\text { Considering actions and } \\
\text { recommendations from } \\
\text { management review in } \\
\text { implementing } \\
\text { organizational changes } \\
\text { by the management }\end{array}$ & 3.7460 & 0.9545 & 0.1956 & 0.1600 & 0.2430 & 0.0474 & 0.1719 \\
\hline 7 & $\begin{array}{l}\text { Role of processes' owners } \\
\text { in control of goals' } \\
\text { achievement and } \\
\text { processes' improvement }\end{array}$ & 3.7460 & 0.8479 & 0.1801 & 0.1134 & 0.1801 & 0.1268 & 0.2802 \\
\hline
\end{tabular}

Source: Authors' work

At Level of responsibility of the sales department for resolving customers' complaints, Level of usage of QMS as a system for managing organization, and Level 
of responsibility of processes' owners for reporting to the management all correlation coefficients with financial results of organizations are statistically insignificant.

At Considering actions and recommendations from internal and external audits in implementing organizational changes by the management, statistically significant values of PCC with financial results of organizations were found at: Income growth level 2013-2014 (PCC 0,1991) and Income growth level 2011-2014 (PCC 0,1929).

At Considering actions and recommendations from management review in implementing organizational changes by the management we found statistically significant values of PCC with financial results of organizations at: Income growth level 2013-2014 (PCC 0,1956) and Income growth level 201 1-2014 (PCC 0,2430).

At Role of processes' owners in control of goals' achievement and processes' improvement we found following statistically significant values of PCC with financial results of organizations: Income growth level 2013-2014 (PCC 0,1801), Income growth level 2011-2014 (PCC 0,1801), and Added value level 2014 (PCC 0,2802).

Correlation coefficients between level of establishment of elements of QMS consistency and financial results or organizations are relatively low. However, correlations between individual financial elements of organizations' business are not (especially) high as well - see Table 4 where correlations between financial results of organizations are presented.

Table 4

Pearson correlation coefficients between financial results of organizations ( $N=126$; $1-a=0.95)$

\begin{tabular}{|c|c|c|c|c|c|c|c|}
\hline $\begin{array}{l}\text { Elements of } \\
\text { financial } \\
\text { operations of } \\
\text { organizations }\end{array}$ & Average & $\begin{array}{l}\text { St. } \\
\text { dev. }\end{array}$ & $\begin{array}{c}\text { Income } \\
\text { growth } \\
\text { level } \\
2013- \\
2014\end{array}$ & $\begin{array}{l}\text { Added } \\
\text { value } \\
\text { growth } \\
\text { level } \\
2013- \\
2014\end{array}$ & $\begin{array}{c}\text { Income } \\
\text { growth } \\
\text { level } \\
2011 \text { - } \\
2014\end{array}$ & $\begin{array}{l}\text { Added } \\
\text { value } \\
\text { growth } \\
\text { level } \\
2011 \text { - } \\
2014\end{array}$ & $\begin{array}{l}\text { Added } \\
\text { value } \\
\text { level } \\
2014\end{array}$ \\
\hline $\begin{array}{l}\text { Income growth } \\
\text { level 2013-2014 }\end{array}$ & 3.0000 & 1.4142 & 1 & 0.4160 & 0.6800 & 0.2240 & 0.3440 \\
\hline $\begin{array}{l}\text { Added value } \\
\text { growth level 2013- } \\
2014\end{array}$ & 3.0000 & 1.4142 & 0.4160 & 1 & 0.3040 & 0.6360 & 0.3280 \\
\hline $\begin{array}{l}\text { Income growth } \\
\text { level 2011-2014 }\end{array}$ & 3.0000 & 1.4142 & 0.6800 & 0.3040 & 1 & 0.4080 & 0.4120 \\
\hline $\begin{array}{l}\text { Added value } \\
\text { growth level 2011- } \\
2014\end{array}$ & 3.0000 & 1.4142 & 0.2240 & 0.6360 & 0.4080 & 1 & 0.4520 \\
\hline $\begin{array}{l}\text { Added value level } \\
2014\end{array}$ & 3.0000 & 1.4142 & 0.3440 & 0.3280 & 0.4120 & 0.4520 & 1 \\
\hline
\end{tabular}

Source: Authors' work

Pearson correlation coefficients between elements of consistency are shown in Table 5. 


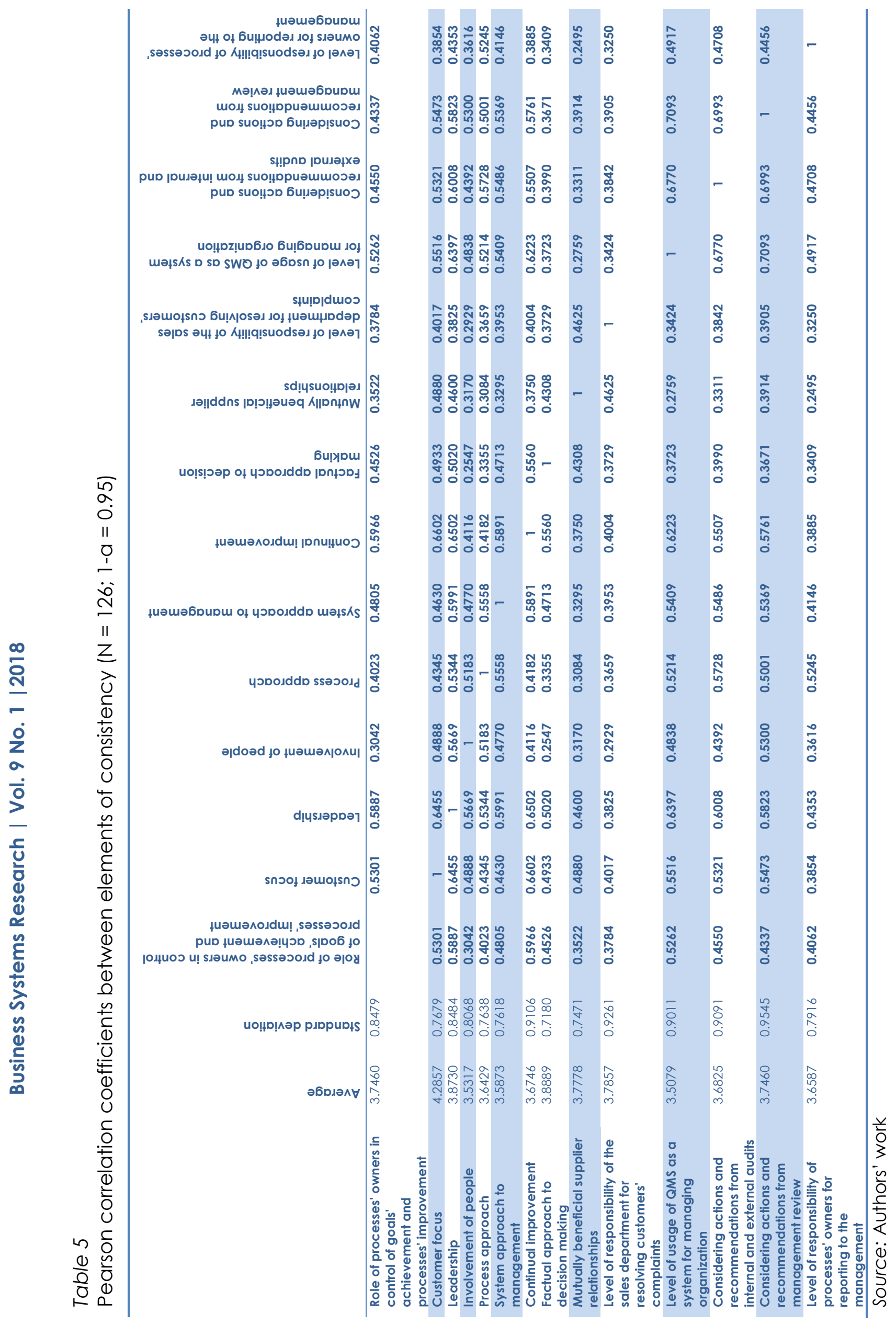


It is interesting that in all elements of QMS consistency mutually statistically significant correlations are evident. Here, we expose only the strongest correlations. Level of usage of QMS as a system for managing organization strongly correlates with following QMS consistency elements: Considering actions and recommendations from management review in implementing organizational changes by the management (PCC 0,7093), and Considering actions and recommendations from internal and external audits in implementing organizational changes by the management (PCC 0,6770).

Considering actions and recommendations from internal and external audits in implementing organizational changes by the management strongly correlates to Considering actions and recommendations from management review in implementing organizational changes by the management (PCC 0,6993).

In the research of QMS characteristics in Slovene organizations, we asked the respondents for their assessment of actual state (1 to 5), and also what would be in their opinion the needed state. In Table 6, influence of the difference between needed and actual level of establishment of elements of QMS consistency on business results of organizations is presented.

The gap between needed and actual characteristics of QMS consistency has significantly negative correlations with several elements.

Gap (needed - actual) for Level of responsibility of the sales department for resolving customers' complaints has significantly negative correlations with Added value growth level 2013-2014 (PCC -0,195).

Gap (needed - actual) for Level of usage of QMS as a system for managing organization has significantly negative correlations with Added value level 2014 (PCC -0,233).

Gap (needed - actual) for Role of processes' owners in control of goals' achievement and processes' improvement has significantly negative correlations with Income growth level 2013-2014 (PCC -0,188), Added value growth level 20132014 (PCC -0,271), Income growth level 201 1-2014 (PCC -0,202), Added value growth level $2011-2014$ (PCC -0,181) and Added value level 2014 (PCC -0,236).

And last but not least, Gap (needed - actual) for Level of responsibility of processes' owners for reporting to the management has significantly negative correlations with Income growth level 2013-2014 (PCC -0,191), Added value growth level 2013-2014 (PCC -0,183), and Added value level 2014 (PCC -0,216).

\section{Discussion}

The research conducted clearly showed that in organizations with QMS certified according to ISO 9001 standard exists the correlation between consistency elements and business results of organizations. By the mean of the research conducted, we managed to confirm hypothesis set on correlation between level of establishment of consistency elements, as seen by quality managers and organizational business results.

The main conclusion of the research is that the correlation between consistency elements and business results of organizations in Slovenia is confirmed. For the majority of consistency elements correlations are significant. In comparison to previous researches presented, added value of this research is not only in the set of relations between elements of consistency and other characteristics of QMS but also in addressing the gap between actual and needed organizational characteristics of QMS and to its influence on business effectiveness. In this, three groups of correlations are exposed: correlation between level of establishment of elements of QMS consistency and financial results of organizations, correlations between QMS 
consistency elements in organizations and, influence of the difference between needed and actual level of establishment of elements of QMS consistency on business results of organizations.

Table 6

Pearson correlation coefficients between assessed difference (needed - actual) of elements of QMS consistency and financial results of organization ( $N=126 ; 1-a=$ 0.95)

\begin{tabular}{|c|c|c|c|c|c|c|c|}
\hline & Average & $\begin{array}{l}\text { Standard } \\
\text { deviation }\end{array}$ & $\begin{array}{l}\text { Income } \\
\text { growth } \\
\text { level } \\
2013- \\
2014\end{array}$ & $\begin{array}{l}\text { Added } \\
\text { value } \\
\text { growth } \\
\text { level } \\
2013- \\
2014 \\
\end{array}$ & $\begin{array}{l}\text { Income } \\
\text { growth } \\
\text { level } \\
2011- \\
2014\end{array}$ & $\begin{array}{l}\text { Added } \\
\text { value } \\
\text { growth } \\
\text { level } \\
2011- \\
2014 \\
\end{array}$ & $\begin{array}{l}\text { Added } \\
\text { value } \\
\text { level } \\
2014\end{array}$ \\
\hline $\begin{array}{l}\text { Role of processes' owners in } \\
\text { control of goals' } \\
\text { achievement and } \\
\text { processes' improvement }\end{array}$ & 0.579 & 0.813 & -0.188 & -0.271 & -0.202 & -0.181 & -0.236 \\
\hline Customer focus & 0.381 & 0.703 & -0.064 & -0.105 & -0.129 & -0.016 & -0.242 \\
\hline Leadership & 0.476 & 0.745 & -0.137 & -0.129 & -0.228 & -0.030 & -0.167 \\
\hline Involvement of people & 0.730 & 0.763 & -0.030 & -0.170 & -0.096 & -0.059 & -0.141 \\
\hline Process approach & 0.556 & 0.765 & -0.015 & -0.141 & -0.089 & -0.044 & -0.096 \\
\hline $\begin{array}{l}\text { System approach to } \\
\text { management }\end{array}$ & 0.571 & 0.731 & -0.039 & -0.209 & -0.070 & -0.108 & -0.093 \\
\hline Continual improvement & 0.746 & 0.857 & -0.172 & -0.198 & -0.205 & -0.145 & -0.350 \\
\hline $\begin{array}{l}\text { Factual approach to } \\
\text { decision making }\end{array}$ & 0.437 & 0.721 & -0.024 & -0.126 & -0.063 & -0.102 & -0.126 \\
\hline $\begin{array}{l}\text { Mutually beneficial supplier } \\
\text { relationships }\end{array}$ & 0.532 & 0.689 & -0.074 & -0.320 & -0.172 & -0.271 & -0.279 \\
\hline $\begin{array}{l}\text { Level of responsibility of the } \\
\text { sales department for } \\
\text { resolving customers' } \\
\text { complaints }\end{array}$ & 0.524 & 0.756 & -0.045 & -0.195 & 0.015 & -0.045 & -0.127 \\
\hline $\begin{array}{l}\text { Level of usage of QMS as a } \\
\text { system for managing } \\
\text { organization }\end{array}$ & 0.619 & 0.875 & -0.058 & -0.110 & -0.116 & -0.052 & -0.233 \\
\hline $\begin{array}{l}\text { Considering actions and } \\
\text { recommendations from } \\
\text { internal and external audits } \\
\text { in implementing } \\
\text { organizational changes by } \\
\text { the management }\end{array}$ & 0.524 & 0.827 & -0.151 & -0.075 & -0.123 & 0.034 & -0.144 \\
\hline $\begin{array}{l}\text { Considering actions and } \\
\text { recommendations from } \\
\text { management review in } \\
\text { implementing } \\
\text { organizational changes by } \\
\text { the management }\end{array}$ & 0.460 & 0.900 & -0.063 & -0.138 & -0.075 & 0.031 & -0.151 \\
\hline $\begin{array}{l}\text { Level of responsibility of } \\
\text { processes' owners for } \\
\text { reporting to the } \\
\text { management }\end{array}$ & 0.611 & 0.681 & -0.191 & -0.183 & -0.174 & -0.083 & -0.216 \\
\hline
\end{tabular}

Source: Authors' work

\section{Conclusion}

In this article, study of QMS characteristics in Slovene organizations is presented in the light of their influence on organizational business results. Correlation analysis leads to some findings that differ from general belief. The research conducted shows current 
state in Slovene organizations. Calculated correlation coefficients between QMS characteristics and business results show their interdependency. For the majority of consistency elements, significant values of PPC with business results are calculated. QMS consistency elements for which we did not manage to prove correlation with business results are: Process approach, Factual approach to decision making, Level of responsibility of the sales department for resolving customers' complaints, Level of usage of QMS as a system for managing organization and, Level of responsibility of processes' owners for reporting to the management. It is however interesting that we manage to prove significant values of PPC for the impact of difference between needed and actual state of consistency elements on business results, for following consistency elements: Customer focus, Leadership, System approach to management, Continual improvement, Mutually beneficial supplier relationships, Level of responsibility of the sales department for resolving customers' complaints and, Level of usage of QMS as a system for managing organization.

Important practical implication of the research conducted is in understanding the correlations and causalities discovered. Due to changes in the environment and the new ISO 9001:2015 quality standard, characteristics of QMS and their impact on organizational business will partly change. Namely, quality management will gradually become integral part of holistic organizational management. Through unified approach to leadership that is incorporated in the new ISO 9001, ISO 14001 and other standards, QMS will influence not only on organizational management system and processes' management but also directly on business results. In that context, good knowledge of QMS characteristics will be valuable asset.

As far as the scope and limitations of the research are considered, the organizations included in the research were from different branches and sectors. 126 of them is relatively small number; higher number of them would definitely contribute to decreasing standard deviation and increasing reliability of results. The research was limited on the territory of Slovenia. We believe that conducting similar research in other countries could be very interesting especially in comparing correlations between QMS characteristics and financial results of organizations.

Another interesting area for further investigation could be to include some additional areas in testing correlations between QMS characteristics and financial results of organizations, such as: level of maturity of QMS, and in this how organizations are involved in more demanding TQM schemes (business excellence, national quality awards, etc.). Here we lean also on some findings of other researchers presented earlier that gave mixed results that were somehow not adequately explained. Additionally, it could be interesting to determine a point or interval on the maturity trajectory where positive impact of QMS on business results occurs beyond any doubts.

\section{References}

1. AJPES - Agency of the Republic of Slovenia for public legal records and related services (2015). Information on Business of Enterprises in the Republic of Slovenia in the Year 2011, AJPES, Ljubljana.

2. Akdere, M. (2011), "An analysis of decision-making process in organizations: Implications for quality management and systematic practice", Total Quality Management \& Business Excellence, Vol. 22, No. 12, pp. 1317-1330.

3. Alič, M. (2014), "Impact of ISO 9001 certification cancellation on business performance: a case study in Slovenian organisations", Total Quality Management \& Business Excellence, Vol. 25, No. 7/8, pp. 790-811. 
4. Asif, M., deBrujin, E. J., Fisscher, O. A. M., Searcy, C. (2010), "Meta management of integration of management system", The TQM Journal, Vol. 22, No. 6, pp. 570-582.

5. Bell, M., Omachou, V. (2011), "Quality system implementation process for business success", International Journal of Quality \& Reliability Management, Vol. 28, No. 7, pp. 732-734.

6. Brown, A. (2013), "Quality: where we come from and what can we expect", The TQM Journal, Vol. 25, No. 6, pp. 585-596.

7. Conti, T. (2010), "System thinking in quality management", The TQM Journal, Vol. 22, No. 4, pp.352-368.

8. Doeleman, H.J., ten Have, S., Ahaus, K. (2012), "The moderating role of leadership in the relationship between management control and business excellence", Total Quality Management \& Business Excellence, Vol. 23, No. 5-6, pp. 591-611.

9. Dong-Yung, K., Kumar, V., Kumar, U. (2012), "Relationship between quality management practices and innovation", Journal of Operations Management, Vol. 30, No. 4, pp. 295-315.

10. Elg, M., Gremyr, I., Hellstöm, A., Witell, L. (2011), "The role of quality managers in contemporary organisations", Total Quality Management \& Business Excellence, Vol. 22, No. 8, pp. 795-806.

11. Karapetrović, S., Casadesus, M. (2009), "Implementing environmental with other standardized management system: scope, sequence time and integration", Journal of Cleaner production, Vol. 17, No. 5, pp. 533-540.

12. Kaynak, H. (2003), "The relationship between total quality management practice and their effects on firm performance", Journal of Operations Management, Vol. 21, No. 4, pp. 405435.

13. Larsson, J., Vinberg, S. (2010), "Leadership behaviour in successful organisations: Universal or situation- dependent?", Total Quality Management \& Business Excellence, Vol. 21, No. 3, pp. 317-336.

14. Liebesman, S. (2008), "Down with silos", Quality Progress, Vol. 41, No. 9, pp. 64-67.

15. Martinez-Costa, M., Choi, T. Y., Martinez, J. A., Martinez-Lorente, A. R. (2009), "ISO9000/1994, ISO 9000/2000 and TQM: The performance debate revisited", Journal of Operations Management, Vol. 27, No. 6, pp. 495-511.

16. Nair, A. (2006), "Meta-analysis of the relationship between quality management practice and firm performance - implication for quality management theory development", Journal of Operations Management, Vol. 24, No. 6, pp. 948-975.

17. Prajogo, D., Sohal, A. (2003), "The relationship between TQM practice quality performance and innovation performance: An empirical examination", International Journal of Quality \& Reliability Management, Vol. 20, No. 8, pp.901-918.

18. Saizarbitoria, I. H. (2006), "How quality management models influence company results. Conclusion of an empirical study based on the delphi metod", Total Quality Management, Vol. 17, No. 6, pp. 775-794.

19. Singh, P. J., Power, D., Choung, S. C. (2011), "A resource dependence theory perspective of ISO 9000 managing organizational environment", Journal of Operations Management, Vol. 29, No. 1-2, pp. 49-64.

20. Slovenski inštitut za standardizacijo (2009). SIST EN ISO 9004:2009, Vodenje za trajno uspešnost organizacije - Pristop z vodenjem kakovosti (ISO 9004:2009) (Managing for the sustained success of an organization - A quality management approach), Ljubljana, Slovenia.

21. Sommerhoff, B. (2012), Entwicklung eines Transformationskonzept für den Beruf Qualitätsmanager, Shaker Verlag, Aachen, Germany.

22. Sommerhoff, B. (2013), "Transformation of the quality manager", in Lekič, Z., Benčina, J., Germ, M., Trampuž, M., Kiauta, M., Žargi, G. (Eds), The Answer is Quality - From Vision to Sustainable Results, Slovensko združenje za kakovost in odličnost, Ljubljana, Slovenia, pp. 6.

23. Werner, T., Weckenmann, A. (2012), "Sustainable quality assurance by assuring competence of employees", Measurement: Journal of the International Measurement Confederation, Vol. 45, No. 6, pp. 1534-1539. 
24. Yeung, A. C. I., Cheng, T. C. E., Lai, K. (2006), "An operational and institutional perspective on total quality management", Production and Operations Management, Vol. 15, No. 1, pp. 156-170.

25. Zelnik, M., Maletič, M., Maletič, D., Gomišček, B. (2012), "Quality management systems as a link between management and employees", Total Quality Management \& Business Excellence, Vol. 23, No. 1, pp. 45-62.

26. Zhang, D., Linderman, K., Schroeder, R.G. (2012), "The moderating role of contextual factors on quality management practices", Journal of Operations Management, Vol. 30, No. 1-2, pp. 12-23.

\section{About the authors}

Vinko Bogataj earned his doctoral and master degrees in the area of quality management, and his bachelor degree in mechanical engineering. He works as independent researcher and consultant, and has extensive experience in quality management. Vinko Bogataj frequently co-operates in international conferences. Areas of his scientific interest and research are quality management and engineering. Author can be contacted at vinko.bogataj@guest.arnes.si.

Gordana Žurga holds her doctoral degree in politology, and master degree in economy. She is professor at the Faculty of Organisation Studies in Novo mesto, Slovenia, with national and international experience in quality management and public management. Areas of her scientific interest and research are quality management, project management and public management. Author can be contacted at gordana.zurga@fos.unm.si. 